\title{
An Evaluation on the Physical and Chemical Composition of Coal Combustion Ash and Its Co-Placement with Coal-Mine Waste Rock
}

\author{
Ginting J. Kusuma ${ }^{1,2}$, Hideki Shimada ${ }^{1}$, Takashi Sasaoka ${ }^{1}$, Kikuo Matsui ${ }^{1}$, Candra Nugraha ${ }^{3}$, \\ Rudy S. Gautama ${ }^{2}$, Budi Sulistianto ${ }^{2}$ \\ ${ }^{1}$ Department of Earth Resources Engineering, Faculty of Engineering, Kyushu University, Fukuoka, Japan; ${ }^{2}$ Mining Engineering Research \\ Group, Institute Technology Bandung, Bandung, Indonesia; ${ }^{3}$ Environment Department, PT. Kaltim Prima Coal, Sengata, Indonesia. \\ Email: jaluku@gmail.com
}

Received March 28 ${ }^{\text {th }}, 2012$; revised April 27 $7^{\text {th }}, 2012$; accepted May $25^{\text {th }}, 2012$

\begin{abstract}
In the last few decades, the utilization of coal to generate electricity was rapidly increasing. Consequently, the production of coal combustion ash (CCA) as a by-product of coal utilization as primary energy sources was increased. The physical and geochemical characteristics of CCA were site-specific which determined by both inherent coal-source quality and combustion condition. This study was intended to characterize the physical, chemical and mineralogical properties of a coal-combustion ash (CCA) from a site specific power plant and evaluate the leachate characteristic of some scenario on the co-placement of CCA with coal-mine waste rock. The physical properties such as specific gravity, dry density, porosity and particle size distribution were determined. Chemically, the CCA sample is enriched mainly in silica, aluminum, iron, and magnesium along with a little amount of calcium and sodium which includes in the class $\mathrm{C}$ fly ash category. Moreover, it is found that the mineral phases identified in the sample were quartz, mullite, aragonite, magnetite, hematite, and spinel. Co-placement experiment with mudstone waste rock shows that the CCA, though it has limited contribution to the decreasing permeability, has important contributed to increase the quality of leachate through releasing higher alkalinity. Moreover, addition of CCA did not affect to the increase of the trace metal element in the leachate. Hence, utilization of CCA by co-placement with coal mine waste rock in the dumping area is visible to be implemented.
\end{abstract}

Keywords: Coal Combustion Ash; Characteristic; Co-Placement; Sulfidic Waste Rock

\section{Introduction}

As the effect of the high of world's oil price, coal utilization as primary energy sources becomes more competitive. Accordingly, there has been a major shift of primary energy sources for electricity generation from the fuel oil into coal in the last few decades. This shifting has result in the rose of coal combustion ash (CCA) as the combustion byproduct afterwards.

The chemistry composition and the physical characteristic of the CCA depend on the coal quality burned and its combustion conditions [1]. As the CCA is a byproduct of combustion, it is classified as a waste by itself; however it would become a valuable by-product in numerous environmental and commercial applications due to its pozzolanic, cementitious and alkaline properties [2].

Acid Mine Drainage (AMD) is formed by oxidation of sulfide minerals contain in rocks by reaction with oxygen and water. The oxidation reaction will release acid $\left(\mathrm{H}^{+}\right)$ into water and further will increase acidity and lowering the $\mathrm{pH}$ [3]. As the sulfide contain in coal measure rock, that will be excavated in order to get valuable coal beneath, AMD is considered as one of the most significant environmental issues in most coal surface mines. The increase of mining industry in Indonesia recently has required a more serious attention in dealing with AMD problems.

AMD potential and generation from a mine site is unique due to the site specific condition of rock geochemical and climatic condition, thus, the nature of size of the associated risk and mitigation feasibility will vary from site to site. It is, however, application of such methods to prevent AMD generation sometimes is restricted because of technical or economic constraints and highly dependent on site specific conditions (climate, geographical locations, etc.). Considering the challenge on AMD prevention which mining industry and environmental engineers being faced, a technically and environmentally sustainable as well as cost-effective mine 
waste management techniques need to be investigated and evaluated. Utilization of CCA is one of opportunities in dealing with this situation, rather than conserve the CCA as waste. Several researches has been conducted to investigate the potential use of CCA to control acid generation from sulphidic wastes $[4,5]$ and to neutralize the generated acid mine drainage $[6,7]$.

This research aims to characterize the site specific CCA and simulate the weathering which occurs in various compositions of CCA-Coal mine waste rock co-placement in order to understand the characteristics of leachate quality.

\section{Materials and Experimental Method}

\subsection{Material}

The coal combustion ash was collected from the newly dumped CCA of the mine mouth thermal power plant. The power plant is a private power plant which is owned by PT Kaltim Prima Coal (KPC) located in Sengata, East Kalimantan, Indonesia. At present, this power-plant has total capacity of $10 \mathrm{MW}$ and planned to be expanded up to 30 MW in the near future.

The mine mouth power plant used un-pulverized commercial size of coal with grain size up to $50 \mathrm{~mm}$ in diameter as fuel. It is consumed 39 thousand tons of the sub-bituminous coal per year from the mine-site nearby and produce 6.8 thousand tons of coal combustion ash comprise as fly ash (89\%) and bottom ash (11\%) yearly.

The mudstone overburden, taken from the mine site nearby, is selected to be used for simulation of the CCA-overburden co-placement in order to evaluate the leachate behavior in particular. Selection of mudstone overburden was due to consideration that this lithology was the most common in the mine area. In this simulation, two types of mudstone which had different geochemical characteristic are used to represent the variation of that lithology.

\subsection{Experimental Methods}

\subsubsection{Bulk Physical}

Some of the bulk physical properties that are particularly interest when fly ash is used for co-placement with overburden are particle size distributions, bulk specific gravity and bulk density. The particle size distribution was evaluated based on ASTM D422 [8] while the specific gravity (G) was based on ASTM D854 [9]. Modified compaction tests were performed on the CCA samples following the ASTM1557 [10] procedure to determine the optimum moisture content and the corresponding dry unit weight. The porosity $(\Phi)$ is calculated based the relation formula [11] as follows;

$$
\Phi=(1-(\rho / \mathrm{G}) \times 100 \% .
$$

\subsubsection{Mineralogical, Elemental Composition and Geochemical Static Analysis}

The characteristic of mineralogy and geochemical of the CCA is not only beneficial for knowing its composition, but also helps in its classification for the plausible utilization. The composition characteristic of those two parameters is important in predicting the leachate quality behavior as result of the interaction with water.

The bulk mineralogy was analyzed by XRD analysis using Rigaku RINT 2000 X-ray diffractometer operated at $25 \mathrm{kV}$ and $30 \mathrm{~mA}$ utilizing $\mathrm{Cu} \mathrm{K} \alpha$ radiation $(\lambda=1.524$

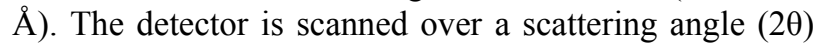
range from $2^{\circ}$ to $65^{\circ}$, with $0.02^{\circ}$ step size and a dwell time $2 \mathrm{~s}$ per step. From the resulting powder diffraction patterns, the crystalline phases are identified by comparing the peak positions and intensities with those in the standard material charts using the JCPDS check system [12]. The chemical composition (major and minor element) characterized by using Rigaku RIX 3100 X-ray fluorescence spectrometer. The unburned carbon content of the coal ash sample is determined by the loss of ignition (LoI) test based on ASTM C-311 by subjecting ovendried ash sample to $750^{\circ} \mathrm{C} \pm 50^{\circ} \mathrm{C}$ in a muffle furnace.

The geochemical static tests are includes acid base accounting (ABA) test, Net Acid Generating (NAG) test and paste $\mathrm{pH}$ and $\mathrm{EC}$. The ABA test itself comprise of determination of maximum potential acid (MPA) based on total sulfur content obtained from XRF analysis (MPA in $\mathrm{kg} \mathrm{H}_{2} \mathrm{SO}_{4} /$ ton $=30.625 \times$ total sulphur-\%), Neutralizing Capacity (ANC) test and calculate the different among those value to determine the net acid production potential (NAPP).

The ANC was used to quantify the inherent acid buffering of sample regarding to acid neutralizing minerals contained within the sample. ANC test was conducted based on the procedure developed by Sobek et al. [13]. This method involves the addition of a known amount of standardized hydrochloric acid $(\mathrm{HCl})$ to an accurately weighed $2 \mathrm{~g}$ of sample, allowing the sample time to react (with heating) for 1 to 2 hours, then back-titrating the mixture with standardized sodium hydroxide $(\mathrm{NaOH})$ to determine the amount of un-reacted $\mathrm{HCl}$. The amount of acid consumed by reaction with the sample is then calculated as ANC and expressed in unit $\mathrm{kg}, \mathrm{H}_{2} \mathrm{SO}_{4} / \mathrm{t}$.

The NAG test [14] was conducted by adding $250 \mathrm{~mL}$ of $7.5 \%$ hydrogen peroxide $\left(\mathrm{H}_{2} \mathrm{O}_{2}\right)$ to 2.5 gram of sample. The peroxide is allowed to react with the sample overnight and at the following day the sample is gently heated to accelerate the oxidation of any remaining sulfides, and then boiled for several minutes to decompose residual peroxide. After cooling to room temperature, 
then titrate the solution by standardized $\mathrm{NaOH}$ to $\mathrm{pH} 4.5$ and then continue to $\mathrm{pH}$ 7. Amount of $\mathrm{NaOH}$ titrated was then used to defined the acidity of solution for $\mathrm{pH} 4.5$ and 7. The acidity of the solution is then used to estimate the net amount of acid produced per unit weight of sample and expressed in unit $\mathrm{kg}, \mathrm{H}_{2} \mathrm{SO}_{4} / \mathrm{t}$.

Paste $\mathrm{pH}$ may indicate the inherent acidity and salinity of the waste material when initially exposed in a waste emplacement area. The test was conducted by measuring the $\mathrm{pH}$ of paste of a soaked pulverized sample in water within ratio of 2:1 for at least 12 hours until overnight.

\subsubsection{Column Leach Test}

Column with $50 \mathrm{~mm}$ in diameter and $150 \mathrm{~mm}$ in height was used in the column leaching experiment. Each column is equipped with a piece of filter paper which installed at the bottom of sample. Six columns with multilayer of material were set-up to simulate scenario of coplacement system and the other three columns were used as control (Figure 1). Particle size between 1 to $2 \mathrm{~cm}$ diameter of the NAF and PAF material was used. Amount of each material composition needed in the column was determined based on percentage weight.

Daily flushing of the de-ionized water was conducted within 0.5 to $0.8 \mathrm{~mL} / \mathrm{g}$ ratio of solid and water. During the flushing process, the infiltration rate of water was also monitored.

The column leaching test was conducted in ten cycles. The number of ten-cycle test used was based on the experience of the column tests conducted in the previous research in which the steady state is reached in the seventh cycle. In addition, this number of cycles is in accordance with the minimum number of test cycles suggested by Sobek [13].

Leachates from the columns following flushing was collected and sampled which then measured for the $\mathrm{pH}$, electrical conductivity (EC) and Oxidation Reduction Potential (ORP). Anion-cation such as calcium, magne- sium, sodium, potassium and sulfate as well as metal content such as iron, aluminum, manganese, chromium, zinc, arsenic, selenium, cadmium, and lead of selected cycle from each column was analyzed after filtered through $0.45 \mathrm{~mm}$ filter. The $\mathrm{pH}, \mathrm{EC}$, and ORP were measured by TOA-DK pH meter HM-21P series, HORIBA conductivity meter B-173, and CUSTOM ORPmeter ORP5041, respectively. Anion-cation was measured by using Dionex ICS-90 ion Chromatography, while metal content was measured by using ICP-MS Agilent 7500 Series.

\section{Result and Discussion}

\subsection{Characteristic of Material}

\subsubsection{Bulk Physical, Chemical and Mineralogical Composition}

The particle distribution of the CCA was shown in the Figure 2. It is observed that the CCA has the median diameter $\left(\mathrm{d}_{50}\right)$ of $0.2 \mathrm{~mm}$ and less than $20 \%$ of fines $(<0.075 \mathrm{~mm})$ with predominantly sand sizes. The coefficient of uniformity $\left(\mathrm{C}_{\mathrm{u}}\right)$ and coefficient of curvature $\left(\mathrm{C}_{\mathrm{c}}\right)$ are 4.73 , and 1.18 , respectively which classified as sand poorly graded (SP) based on Unified Soil Classification System. The coarse particle size may due to the effect of the utilization of commercial size coal $(<50 \mathrm{~mm})$, which is un-pulverized prior to feed up to the boiler. This coalfeeding method has caused low efficiency of coal burning in the boiler, hence a quite high amount of coal remain un-burned as indicated by significant lost on ignition-LOI value up to $14.4 \%$ was occurred afterwards. Specific gravity $\left(\mathrm{S}_{\mathrm{g}}\right)$ of CCA was 1.24 . Maximum dry unit weight of $6.3 \mathrm{kN} / \mathrm{m}^{3}$ and porosity of $45.97 \%$ were obtained from compaction test at optimum moisture content of $65 \%$.

Major elemental composition of the CCA sample was shown in Table 1. The major elements were silica, aluminum, iron, magnesium, calcium and potassium oxide $(>1 \%)$ and followed by sulfur, titanium, barium, sodium and phosphate which are less than $1 \%$.
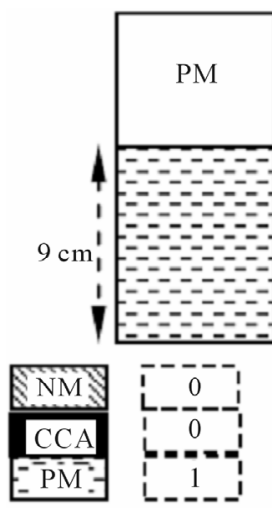
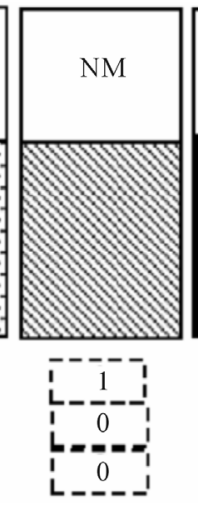
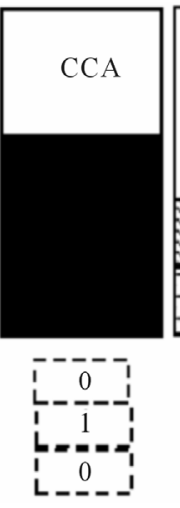
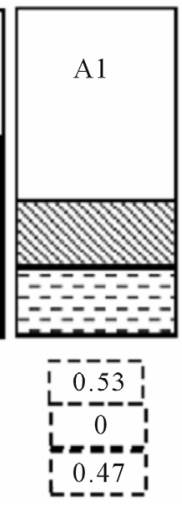
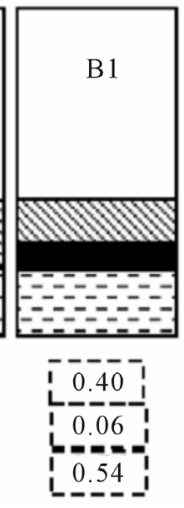
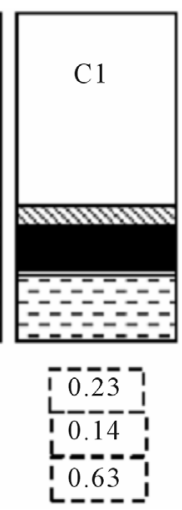
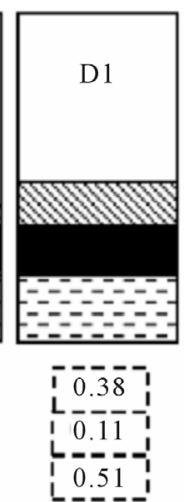
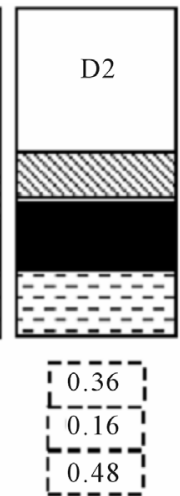

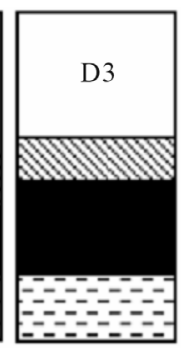

$\overline{0} \overline{34} \overline{1}$ L $0-18-1$ (0.46

Figure 1. Column test scenario. 


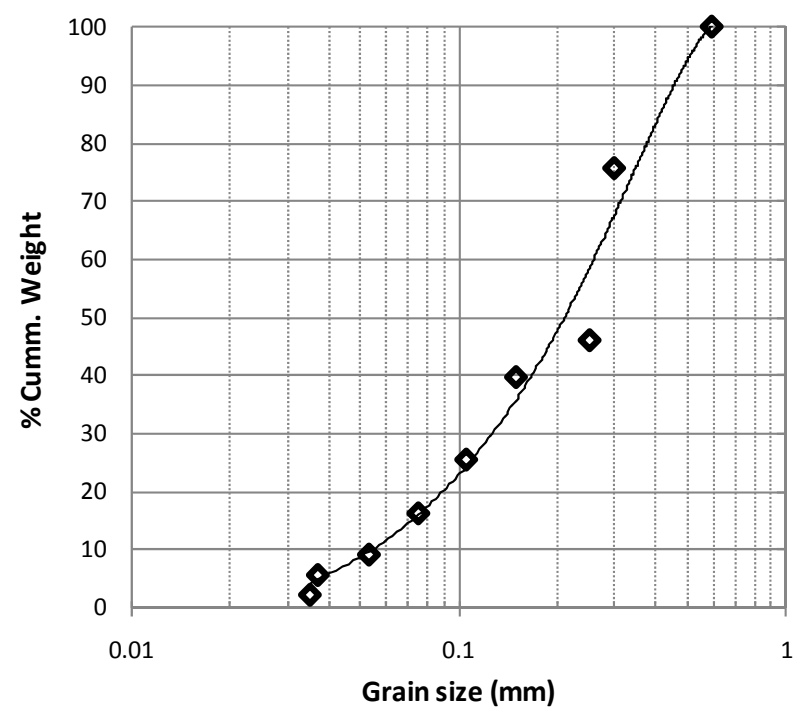

Figure 2. Particle size distribution of CCA.

Table 1. Bulk elemental composition of sample.

\begin{tabular}{cccc}
\hline \multicolumn{2}{c}{ Major Element (Mass \%) } & \multicolumn{2}{c}{ Major Element (Mass \%) } \\
\hline $\mathrm{SiO}_{2}$ & 32.627 & $\mathrm{Na}_{2} \mathrm{O}$ & 0.206 \\
$\mathrm{TiO}_{2}$ & 0.669 & $\mathrm{~K}_{2} \mathrm{O}$ & 1.446 \\
$\mathrm{Al}_{2} \mathrm{O}_{3}$ & 13.961 & $\mathrm{P}_{2} \mathrm{O}_{5}$ & 0.225 \\
$\mathrm{FeO}$ & 6.462 & $\mathrm{~S}$ & 0.969 \\
$\mathrm{MnO}$ & 0.019 & $\mathrm{Ba}$ & 0.400 \\
$\mathrm{MgO}$ & 3.045 & $\mathrm{LOI}$ & 14.36 \\
$\mathrm{CaO}$ & 2.67 & $\mathrm{H}_{2} \mathrm{O}$ & 22.71 \\
\hline
\end{tabular}

The sum value of the silica, aluminum and iron oxide which was more than $50 \%$ classifies this CCA into the class $\mathrm{C}$ fly ash [15]. Although it has pozzolanic properties, due to its low content of lime (calcium oxide-CaO), the cementitious properties of this CCA was low [16-18].

Based on the XRD analysis results, the CCA was consisted of quartz, mullite, aragonite, magnetite, hematite and spinel, while both NM and PM rock samples comprised of quartz, illite \& kaolinite, siderite, and pyrite (Figure 3). The existence of pyrite on both rock samples mean that those to rock sample has capacity to produce acidity.

\subsubsection{Geochemical Static Test}

Result of geochemical analysis of samples was shown in Table 2. NAPP value of CCA, NM and PM are $-40.1 \mathrm{~kg}$ $\mathrm{H}_{2} \mathrm{SO}_{4} /$ ton, $-40.8 \mathrm{~kg} \mathrm{H}_{2} \mathrm{SO}_{4} /$ ton, and $63.3 \mathrm{~kg} \mathrm{H}_{2} \mathrm{SO}_{4} /$ ton, whereas the NAG pH was 7.4, 3.2 and 2.1, respectively.

Combining value of NAPP and NAG pH of each those samples, CCA was classified as Non Acid Forming (NAF) material, PM was classified as potentially acid forming (PAF) material, while NM was classified as
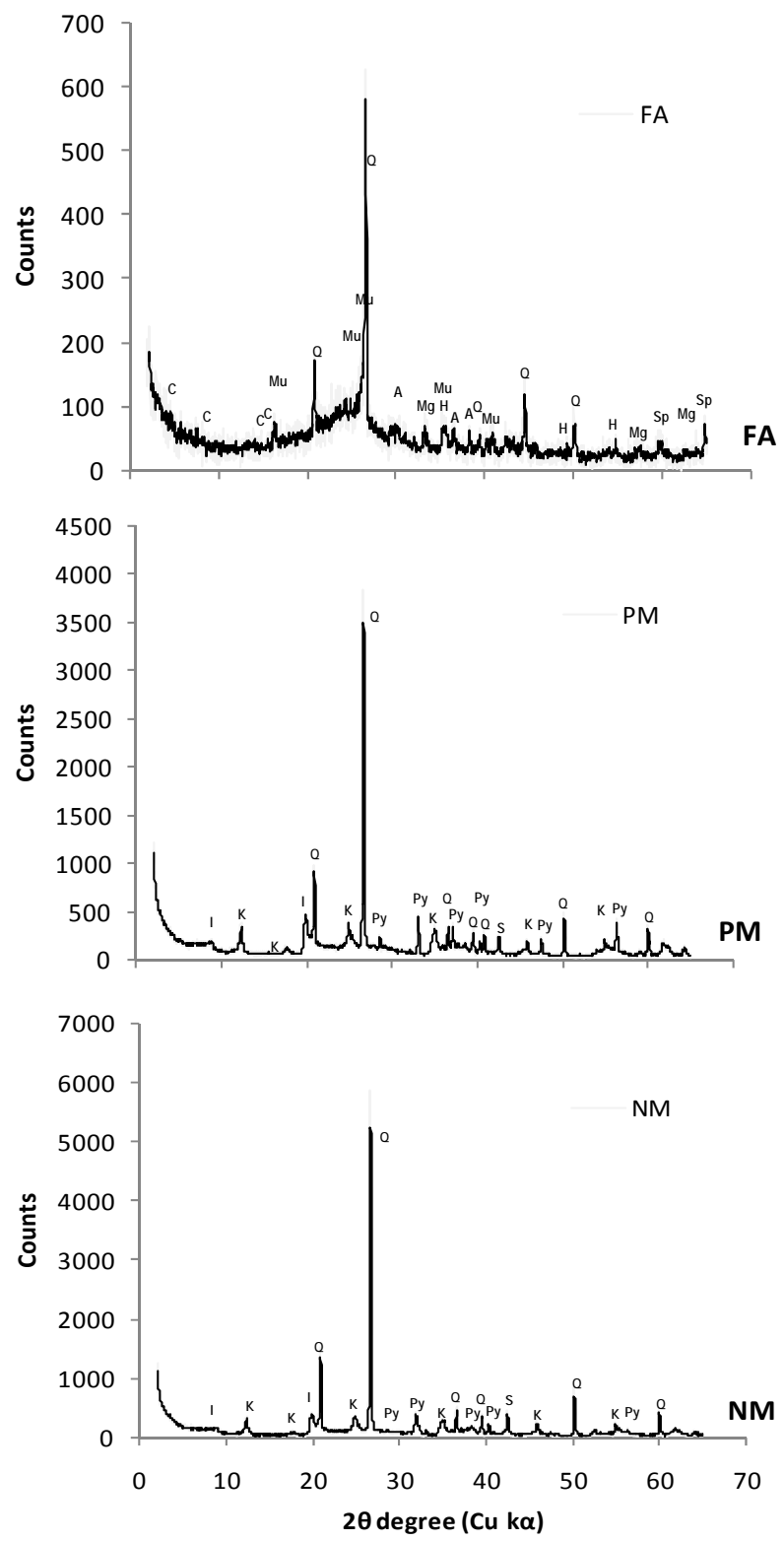

Figure 3. X-ray diffraction pattern of CCA and waste rock samples.

"uncertain" due to conflict between NAPP and NAG pH value criteria. In term of NM sample, the quite low NAG $\mathrm{pH}$ value, which strengthens by paste $\mathrm{pH}$, indicate that the sample may content the reactive sulfide mineral or residual weathering products. However, considering the quite high ANC value and low NAG value for $\mathrm{pH} 7(<10$ $\mathrm{kg} \mathrm{H}_{2} \mathrm{SO}_{4} /$ ton), the NM sample is likely classified as NAF Material.

\subsection{Physical Characteristic and Permeability of the Column Leach Test}

Visually, physical change observed in the samples at each 
Its Co-Placement with Coal-Mine Waste Rock

Table 2. Geochemical static test result.

\begin{tabular}{cccccccccc}
\hline Sample & Paste $\mathrm{pH}$ & $\begin{array}{c}\text { Paste EC } \\
(\%)\end{array}$ & $\begin{array}{c}\mathrm{S} \\
\left(\mathrm{Kg} \mathrm{H}_{2} \mathrm{SO}_{4} / \text { ton }\right)\end{array}$ & ANC & NAPP & NAG pH & \multicolumn{2}{c}{ NAG } \\
\hline CCA & 8.9 & 2.8 & 0.97 & 69.8 & -40.1 & 7.4 & & \\
NM & 3.8 & 8.9 & 0.37 & 51.5 & -40.8 & 3.2 & 2.9 & 6.3 \\
PM & 1.7 & 19.8 & 2.07 & 0 & 63.3 & 2.1 & 95.1 & 110.2 \\
\hline
\end{tabular}

Note $:$ ANC $=$ Acid neutralizing capacity NAPP $=$ Nett acid producing potential $; \mathrm{NAG}=$ Net acid generation.

column is color changes in the area of each material contact zone, while the grain size reduction of sample is not significantly occurred (Figure 4).

The color change of the rock sample was due to the effect of chemical precipitation of dissolve metal ion. The yellow-orange solid material formed is expected as the ferric-oxyhydroxides, common precipitated mineral related to the AMD generation. The precipitation is determined by some aspect such as the $\mathrm{pH}$ of pore water and the concentration of dissolve metal. The existence of neutralization reaction within pore water may increase the $\mathrm{pH}$ of pore water that may reduce the solubility of the dissolved metal in the liquid.

In term of grain size degradation, the plausible reason why it little occurred in the rock sample was due to the room temperature environment implemented. Consequently, the rock sample did not experience enough drying, thus rock deterioration due to slaking phenomenon was inadequate [19]. As consequences of this condition, the formation of clay size particle (the dominant particle size constituent of mudstone) that may contribute to fill voids among grain was limited, hence the permeability remain high in the column. As it is known that low permeability has important role to minimize water infiltration and oxygen diffusion rate in the material layer that control oxidation reaction rate of sulfide mineral to generate the acid [20]. Gautama 2010 reported that permeability of CCA-mudstone mix layer is determined by the weathering

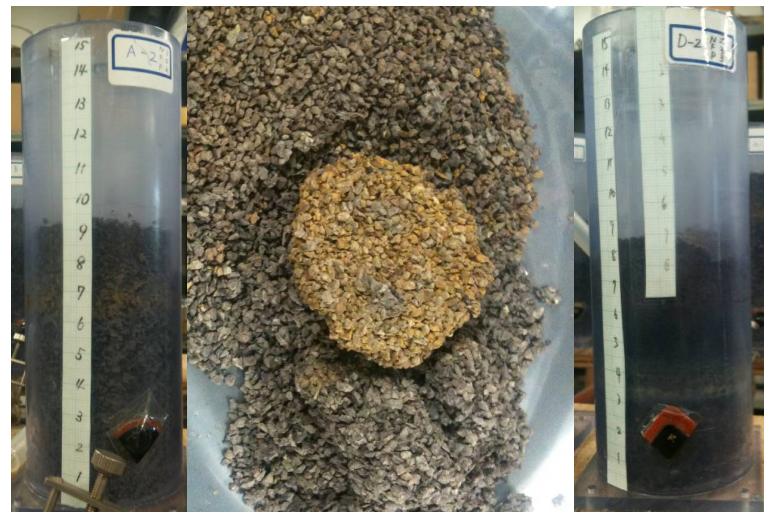

Figure 4. Column condition and the color change. of mudstone rather than the CCA weathering [5]. This condition may become a weakness in term of the utilization of this CCA type.

\section{3. pH, Electric Conductivity and Oxidation-Reduction Potential}

In general, the trend of the measured $\mathrm{pH}$ value of each column can be divided into two groups. The NAF and CCA control column produced leachate with high $\mathrm{pH}$ values, and the PAF columns has the lowest $\mathrm{pH}$ values whereas the $\mathrm{pH}$ value of leachate from the multi-layer material column with different composition was laid in between of those $\mathrm{pH}$ range (Figure 5).

The $\mathrm{pH}$ of the CCA column is the highest (around 8) with a downward trend which indicate decrease on dissolution rate as well as availability of alkaline elements in the column. At the NAF column, after the initial increased of $\mathrm{pH}$ value from 4.78 to 7.15 at the fifth cycle, the $\mathrm{pH}$ value tends to decrease in the range of 6.5 . Relatively low $\mathrm{pH}$ value at the beginning cycle is in accordance with paste $\mathrm{pH}$ data from static test. It indicates the presence of residual acid which then dissolved that cannot be balanced by dissolution rate of alkaline minerals in the sample to produce neutral $\mathrm{pH}$.

In contrast, the $\mathrm{pH}$ value in the PAF column and the multi-layer material column tends to increase during the

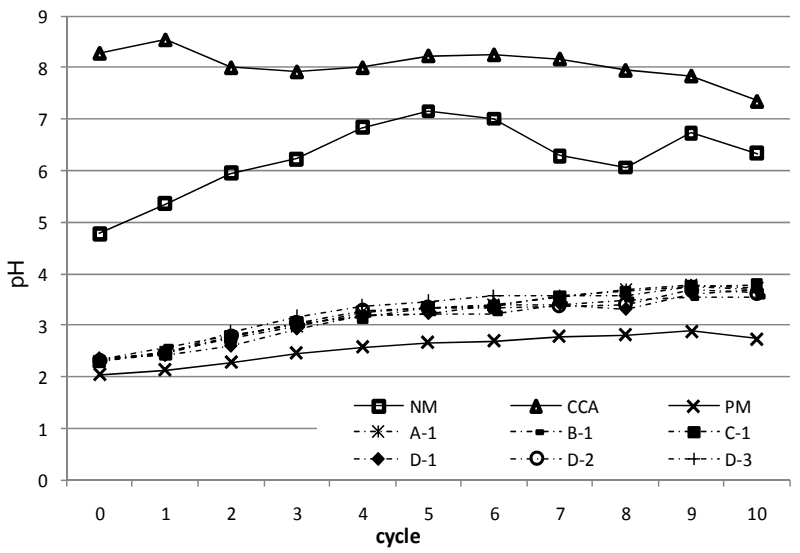

Figure 5. The pH of leachate. 
experiment. The $\mathrm{pH}$ value in the PAF column was increased from 2.05 at initial to be 2.74 at tenth cycle. Similar trend was also occurred in the $\mathrm{pH}$ values in the multi-layer columns which increased from $\mathrm{pH} 2.2$ to $\mathrm{pH}$ 3.79 at last cycle. It was indicated a decrease of acid production rate on the samples. The higher $\mathrm{pH}$ values in the multi-layer columns compared with PAF column shows the effect of the NAF and CCA material addition that gives alkaline donors which will consume the acid generated by PAF material and raise the $\mathrm{pH}$ of leachate ultimately. In addition, the higher composition of CCA resulting the higher $\mathrm{pH}$ due to the higher neutralizing capacity.

The electric conductivity which reflects the total amount of dissolved ions in the leachate has an opposite order with the $\mathrm{pH}$ where the lower $\mathrm{pH}$ has result in the higher EC value (Figure 6). Moreover, the thicker layer of CCA has produced the lower EC. The effect of neutralization and adsorption of the ion by the CCA, especially from the top NAF layer, may explain this phenomenon.

The ORP trend order has an almost similar trend order with the EC. The Eh-pH diagram was used to predict the stability of metal in the solution. Figure 7 shows the plotted experiment data into the Eh-pH diagram of the iron. It is revealed that the dissolved iron of CCA column is tending to precipitate as the dissolved iron in the NAF column. Most of the dissolved iron in the PAF and the multi-layer material column is estimated remain stable as $\mathrm{Fe}^{2+}$, although the trend is shift to be precipitated due to the increase $\mathrm{pH}$ value. This mechanism may explain the forming of the yellow-orange colloid in the contact of each layer which is caused by the precipitation of dissolved iron in the form of ferric (oxy)-hydroxides.

\subsection{Anion-Cation and Metal Content of the Column Leach Test}

After rapid decrease in the first fourth cycles, the steady release rate phase of the anion-cation has been achieved.

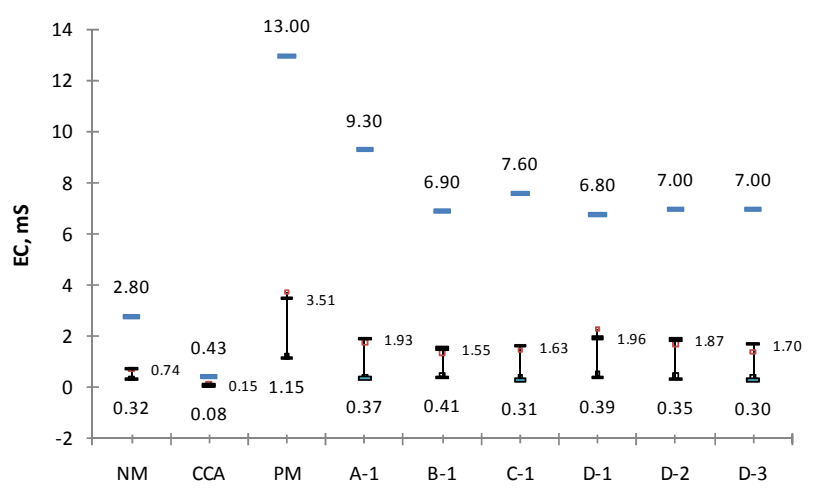

Figure 6. Electric conductivity of the leachate.

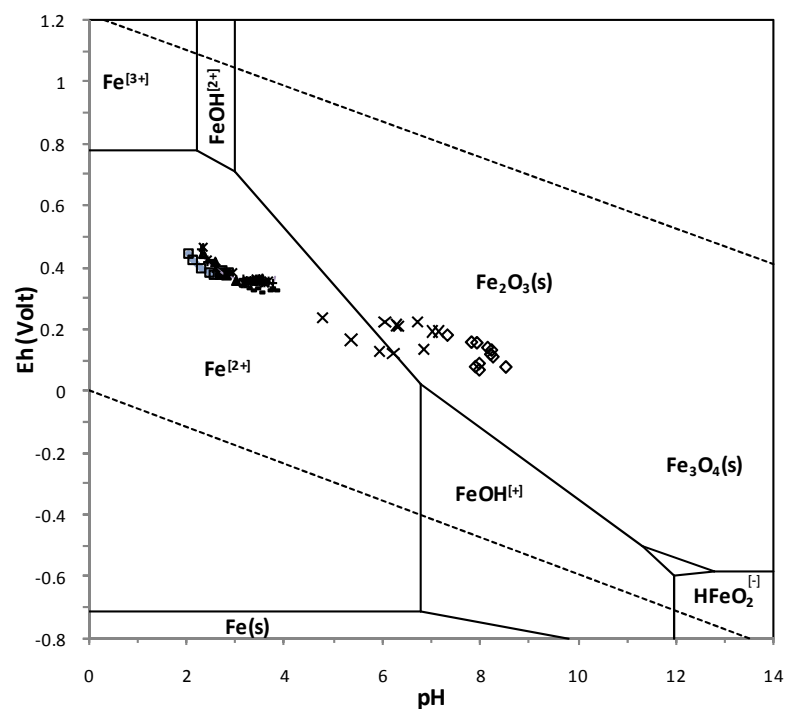

Figure 7. Plot of leachate quality into Fe-Eh-pH diagram (Takeno 2005). $\Sigma \mathrm{Fe}=10^{-10}, 298.15 \mathrm{~K}$ and $10^{5} \mathrm{~Pa}$.

Amount of sulfate was significantly decrease in the first forth cycle, from range $2.000-13.000 \mathrm{mg} / \mathrm{L}$ at the first cycle to less than $250 \mathrm{mg} / \mathrm{L}$ at cycle 7, except PAF Column (see Figure 8). While the cations were decrease from hundreds of $\mathrm{mg} / \mathrm{L}$ to around $15-25 \mathrm{mg} / \mathrm{L}$. Comparing the ratio of sulfate and the measured cations, which gave the ratio from less than 0.1 to more than 2 (see Figure 9), with the $\mathrm{EC}$ and $\mathrm{pH}$ value show that the trend of this sulfate-alkali ratio was consistent with the $\mathrm{EC}$ and in reverse with the $\mathrm{pH}$ value. This is meant that the equilibrium of anion-cation in the solution will determined the quality of the solution.

Regarding to the addition of CCA, it was revealed that addition of CCA has resulting in higher alkali release rate, meant that there is more alkali available to neutralize acid. Those conditions also effect to the release rate of major metal such as iron, aluminum and manganese which is the lower concentration of those metals found in the column with higher CCA ratio as shown at Table 3.

Furthermore, the trace metal release concentration of addition CCA up to $18 \% \mathrm{w} / \mathrm{w}$ was remain lower than the multi-layer column without CCA which meant that addition of CCA to reduce the NAF utilization did not effect to the increase of the measured trace metal element (Table 4).

\section{Conclusion}

Based on the result of this study, the following conclusion can be drawn: 1) The CCA used in this experiment classified as class $\mathrm{C}$ fly ash with low content of lime. In addition, the mineral phases identified in the ash samples are quartz, mullite, magnetite, and hematite. 2) The permeability in the column, which will control the water infiltration 

Its Co-Placement with Coal-Mine Waste Rock

Table 3. Major metal content in leachate.

\begin{tabular}{|c|c|c|c|c|c|c|c|c|c|}
\hline & \multicolumn{3}{|c|}{$\mathrm{Fe}(\mathrm{mg} / \mathrm{L})$} & \multicolumn{3}{|c|}{$\mathrm{Al}(\mathrm{mg} / \mathrm{L})$} & \multicolumn{3}{|c|}{$\mathrm{Mn}(\mathrm{mg} / \mathrm{L})$} \\
\hline & $\max$ & avrg & $\min$ & $\max$ & avrg & $\min$ & $\max$ & avrg & $\min$ \\
\hline NM & 121.8 & 46.6 & 17.9 & 25.6 & 9.1 & 3.4 & 4.2 & 1.9 & 0.9 \\
\hline FA & 24.5 & 13.9 & 6.6 & 5.5 & 3.8 & 3.1 & 0.3 & 0.3 & 0.3 \\
\hline $\mathrm{PM}$ & 5080.2 & 1497.4 & 249.9 & 691.5 & 201.4 & 35.4 & 43.2 & 15.6 & 4.9 \\
\hline A1 & 2142.0 & 701.5 & 181.7 & 314.2 & 123.7 & 43.3 & 31.9 & 13.2 & 6.2 \\
\hline B1 & 1282.8 & 484.6 & 185.3 & 175.0 & 92.0 & 36.0 & 35.7 & 13.7 & 3.4 \\
\hline $\mathrm{C} 1$ & 1667.7 & 552.0 & 58.6 & 222.3 & 77.8 & 20.8 & 111.8 & 33.2 & 5.0 \\
\hline D1 & 5020.3 & 1413.9 & 146.3 & 917.1 & 261.6 & 26.9 & 67.3 & 20.8 & 4.9 \\
\hline D2 & 2977.6 & 883.7 & 157.3 & 494.0 & 142.9 & 20.5 & 60.2 & 18.4 & 3.4 \\
\hline D3 & 2489.9 & 775.7 & 117.9 & 415.3 & 123.8 & 20.8 & 88.9 & 28.5 & 7.2 \\
\hline
\end{tabular}

Table 4. Trace metal content in the leachate.

\begin{tabular}{|c|c|c|c|c|c|c|c|c|c|c|c|c|c|c|c|c|c|c|}
\hline & \multicolumn{3}{|c|}{$\mathrm{Cr}(\mathrm{mg} / \mathrm{L})$} & \multicolumn{3}{|c|}{$\mathrm{Zn}(\mathrm{mg} / \mathrm{L})$} & \multicolumn{3}{|c|}{ As $(m g / L)$} & \multicolumn{3}{|c|}{$\mathrm{Se}(\mathrm{mg} / \mathrm{L})$} & \multicolumn{3}{|c|}{$\mathrm{Cd}(\mathrm{mg} / \mathrm{L})$} & \multicolumn{3}{|c|}{$\mathrm{Pb}(\mathrm{mg} / \mathrm{L})$} \\
\hline & $\max$ & avrg & $\min$ & $\max$ & avrg & $\min$ & $\max$ & avrg & $\min$ & $\max$ & avrg & $\min$ & $\max$ & avrg & $\min$ & $\max$ & avrg & $\min$ \\
\hline NM & 2.1 & 1.1 & 0.3 & 5.7 & 4.1 & 2.9 & 1.3 & 0.7 & 0.4 & 7.4 & 3.4 & 1.6 & 0.75 & 0.35 & 0.12 & 10.0 & 3.6 & 1.2 \\
\hline FA & 0.5 & 0.3 & 0.2 & 3.4 & 3.2 & 2.9 & 0.4 & 0.3 & 0.2 & 6.2 & 2.8 & 1.4 & 0.12 & 0.06 & 0.04 & 1.6 & 0.9 & 0.4 \\
\hline $\mathrm{PM}$ & 3.7 & 3.0 & 2.5 & 200.5 & 95.8 & 53.2 & 7.2 & 5.5 & 4.3 & 25.0 & 23.3 & 22.3 & 0.10 & 0.09 & 0.06 & 12.4 & 8.0 & 6.1 \\
\hline A1 & 3.8 & 3.4 & 3.1 & 142.7 & 94.8 & 55.4 & 4.4 & 3.8 & 3.2 & 21.5 & 20.1 & 18.2 & 0.52 & 0.37 & 0.24 & 11.3 & 9.2 & 7.1 \\
\hline B1 & 4.8 & 3.7 & 3.1 & 161.8 & 94.5 & 50.5 & 3.6 & 3.4 & 3.2 & 23.9 & 21.4 & 18.5 & 0.26 & 0.14 & 0.08 & 14.7 & 8.7 & 6.0 \\
\hline $\mathrm{C} 1$ & 3.9 & 3.1 & 2.6 & 143.3 & 84.8 & 48.9 & 3.2 & 3.0 & 2.7 & 25.4 & 22.3 & 20.2 & 0.12 & 0.11 & 0.08 & 11.9 & 7.6 & 3.6 \\
\hline D1 & 4.2 & 3.6 & 2.9 & 138.7 & 77.5 & 53.0 & 2.9 & 2.5 & 1.9 & 23.6 & 22.7 & 22.2 & 0.12 & 0.07 & 0.04 & 12.5 & 8.3 & 6.2 \\
\hline D2 & 4.3 & 3.4 & 2.8 & 86.0 & 63.6 & 50.8 & 2.6 & 2.2 & 2.0 & 23.7 & 23.2 & 22.6 & 0.14 & 0.09 & 0.06 & 8.9 & 5.9 & 3.0 \\
\hline D3 & 4.5 & 3.7 & 3.4 & 89.9 & 65.2 & 46.2 & 2.9 & 2.3 & 1.8 & 24.4 & 22.4 & 18.8 & 0.12 & 0.07 & 0.02 & 17.5 & 9.8 & 5.4 \\
\hline TCLP $^{*}$ & & 5 & & & 50 & & & 5 & & & 1 & & & 1 & & & 5 & \\
\hline
\end{tabular}

Note: *Indonesian government regulation. No. 18/1999 jo Gov. Reg No. 85/1999.

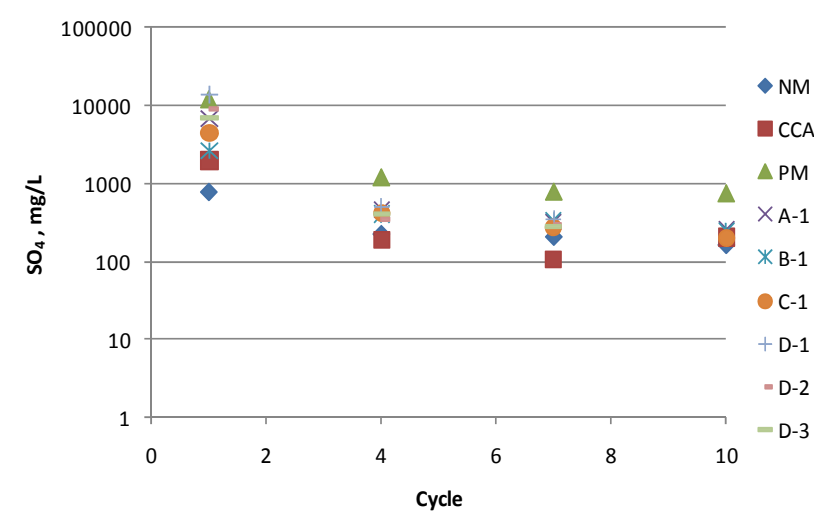

Figure 8. Concentration of sulfate in the leachate.

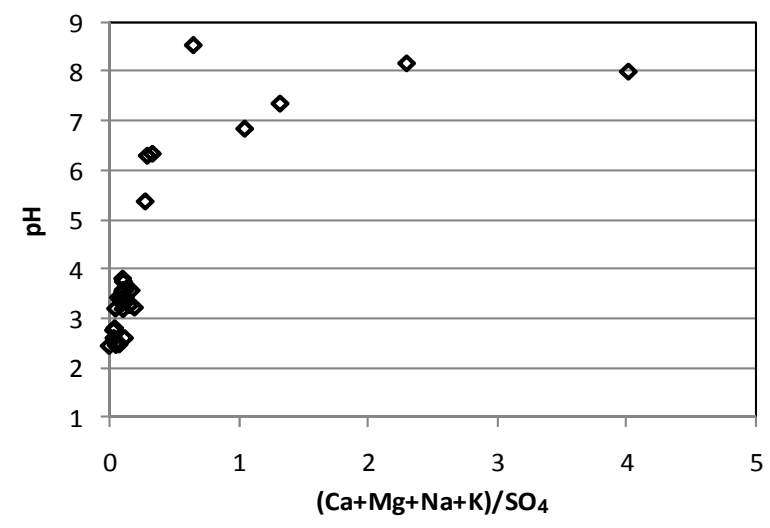

Figure 9. Ratio of cation-sulfate in the leachate. 
and oxygen diffusion, was mainly determined by the deterioration of waste rock rather than the CCA weathering. 3) Precipitation of secondary mineral as the effect of neutralization reaction was occurred in the contact of each material layer. 4) The addition of CCA resulting in higher alkali release rate, which then affect to lower major dissolved metal. 5) An addition of CCA up to $18 \% \mathrm{w} / \mathrm{w}$ in the co-placement scenario with waste rock material did not affect to the increase of trace metal content in the leachate. Furthermore, it can be concluded that minimizing AMD generation by using CCA was visible to be implemented. However, a scale-up simulation on field condition is necessary to investigate the influence of the external conditions, such as local climate and the higher particle size, to the performance of the covering scenario by using CCA.

\section{Acknowledgements}

Authors would like to thank to PT Kaltim Prima Coal for providing the CCA \& rock sample and also for the continuous support and co-operation for years. First author would thank to Japanese Ministry of Education, Culture, Sports, Science and Technology (MEXT) and Global COE, Kyushu University "Novel Carbon Resources" for financial support. First author would also thank to Mr. Suichi Fujita, Mr. Ko Hiroto and Ms. Akane Gondo who kindly helped performing the laboratory test.

\section{REFERENCES}

[1] L. J. Wibberley and T. F. Wall, "An Investigation of Factors Affecting the Physical Characteristics of Flyash Formed in a Laboratory Scale Combustor," Combustion Science and Technology, Vol. 48, No. 3-4, 1986, pp. 177190

[2] M. B. Yeheyis, J. Q. Shang and E. K. Yanful, "Characterization and Environmental Evaluation of Atikokan Coal Fly Ash for Environmental Applications," Journal of Environmental Engineering and Science, Vol. 7, No. 5, 2008, pp. 481-498. doi:10.1139/S08-019

[3] W. Stumm and J. J. Morgan, "Aquatic Chemistry: An Introduction Emphasizing Chemical Equilibria in Natural Waters," 3rd Edition, John Wiley and Sons, New York, 1996.

[4] A. Xenidis, E. Mylona and I. Paspaliaris, "Potential Use of Lignite Fly Ash for the Control of Acid Generation from Sulphidic Wastes," Waste Management, Vol. 22, 2002, pp. 631-641.

[5] R. S. Gautama, G. J. Kusuma, I. Lestari and R. P. Anggana, "Weathering Behaviour of Overburden-Coal Ash Blending in Relation to Overburden Management for Acid Mine Drainage Prevention in Coal Surface Mine,"
2010.

[6] R. Pérez-López, J. M. Nieto and G. R. de Almodóvar, "Utilization of Fly Ash to Improve the Quality of the Acid Mine Drainage Generated by Oxidation of a Sulphide-Rich Mining Waste: Column Experiments," Chemosphere, Vol. 67, No. 8, 2007, pp. 1637-1646. doi:10.1016/j.chemosphere.2006.10.009

[7] W. Gitari, L. Petrik, O. Etchebers, D. Key, E. Iwuoha and C. Okujeni, "Passive Neutralisation of Acid Mine Drainage by Fly Ash and Its Derivatives: A Column Leaching Study," Fuel, Vol. 87, No. 8-9, 2008, pp. 1637-1650. doi:10.1016/j.fuel.2007.08.025

[8] ASTM (D422), "Standard Test Method for Particle Size Analysis," ASTM International.

[9] ASTM (D854), "Standard Test for Specific Gravity of Soil Solids by Water Pycnometer," ASTM International.

[10] ASTM (D1557), "Standard Test Methods for Laboratory Compaction Characteristics of Soil Using Modified Effort," ASTM International.

[11] D. P. Mishra and S. K. Das, "A Study of PhysicoChemical and Mineralogical Properties of Talcher Coal Fly Ash for Stowing in Underground Coal Mines," Materials Characterization, Vol. 61, No. 11, 2010, pp. 12521259. doi:10.1016/j.matchar.2010.08.008

[12] P. Y. Chen, "Table of Key Lines in X-Ray Powder Diffraction Patterns of Minerals in Clays and Associated Rocks," 1977.

[13] A. A. Sobek, W. A. Schuller, J. R. Freeman and R. M. Smith, "Field and Laboratory Methods Applicable to Overburden and Minesoils," 1978.

[14] AMIRA International, ARD Test Handbook, 2002.

[15] ASTM (C618-08), "Standard Specification for Coal Fly Ash and Raw or Calcined Natural Pozzolan for Use in Concrete," ASTM International.

[16] Q. Xu and J. Fan, "Self-Cementitious Property of High Calcium Fly Ash," Coal Ash China, No. 6, 1994, pp. 2327.

[17] E. L. Ye, "Self-Harden Mechanism of High Calcium Fly Ash," Housing Materials \& Applications, No. 5, 1996, pp. 40-42.

[18] I. A. Sadisun, H. Shimada, M. Ichinose and K. Matsui, "Study on the Physical Disintegration Characteristics of Subang Claystone Subjected to a Modified Slaking Index Test," Geotechnical and Geological Engineering, Vol. 23, 2005, pp. 199-218.

[19] S. Devasahayam, "Application of Particle Size Distribution Analysis in Evaluating the Weathering in Coal Mine Rejects and Tailings," Fuel Processing Technology, Vol. 88, No. 3, 2007, pp. 295-301. doi:10.1016/j.fuproc.2006.10.013

[20] N. Takeno, "Atlas of Eh-pH Diagrams," Geological Survey of Japan Open File Report, 2005. 